\title{
PENERAPAN MODEL PEMBELAJARAN KOOPERATIF TIPE GROUP INVESTIGATION UNTUK MENINGKATKAN HASIL BELAJAR PESERTA DIDIK
}

\section{Rachmat Arif Ibrahim}

SMA Negeri 2 Leuwidamar Banten, Indonesia

Email: rachmati485@gmail.com

\section{Abstract}

Class Action Research with the aim to know the model of Cooperative Learning Type Investigation Group can be the result of learning students on redox reaction material and electrolysis class XII IPA-1 SMA Negeri 2 Leuwidamar. Ongoing learning Investigation Group Hoping to be the results of learning students class XII IPA-1. Which variables are the Use of Cooperative Model Learning Type Investigation Group $(X)$ and Learner Learning Outcomes $(Y)$. Which data are qualitative and quantitative data from the results of Final Research I, II and Grade III through the Education Process in Class XII IPA-1 SMA Negeri 2 Leuwidamar Lebak Regency. The results of the study concluded that Cooperative Learning Type Investigation Group is very and interesting for learning learning. The result of the following data : a. Activity level is good from the average age I value of $42.85 \%$, among which is $59.52 \%$ and age iii by $90.48 \%$; B. Teacher planning in the time carried out in the course of healthy quarter I score 4.58, score ii at 4.68 and grade III score 5.00 and Communication process on on score I 3.78, on score II 4.35 and score III 4.75; score 4.75 ; score score c. Student learning outcomes, before complete education students there are 5 (14.29\%), life I there are 11 (31.43\%), grade II there are 18 (51.43\%) and among others there are 30 (85.71\%). So it can be concluded that the use of Model Learning Type Investigation Group can increase the activities of students who are in the aftermath of the results of learning.

Keywords: learning outcomes; cooperative learning model; type group investigation

\section{Abstrak}

Penelitian Tindakan Kelas dilakukan dengan tujuan untuk mengetahui penerapan Model Pembelajaran Kooperatif tipe Group Investigation dapat meningkatkan hasil belajar peserta didik pada materi reaksi redoks dan elektrolisis kelas XII IPA-1 SMA Negeri 2 Leuwidamar. Pelaksanaan pembelajaran Group Investigation diharapkan dapat meningkatkan hasil belajar peserta didik kelas XII IPA-1. Variabel yang diamati adalah Penggunaan Model Koperatif Learning tipe Group Investigation (X) dan Hasil Belajar peserta didik (Y). Data yang digunakan adalah data kualitatif dan data kuantitatif yang diperoleh dari hasil Penelitian Siklus I, II dan Siklus III melalui Proses Pembelajaran di Kelas XII IPA-1 SMA Negeri 2 Leuwidamar Kabupaten Lebak. Hasil penelitian disimpulan bahwa Pembelajaran Koperatif Learning tipe Group Investigation sangat efektif dan menarik untuk diterapkan dalam proses pembelajaran. Hasil pembahasan data-data berikut : a.

\begin{tabular}{lllll}
\hline How to cite: & Ibrahim, Rachmat Arif (2021) Penerapan Model Pembelajaran Kooperatif Tipe Group Investigation \\
& untuk Meningkatkan Hasil Belajar & Peserta & Didik, & Syntax \\
& http://dx.doi.org/10.36418/syntax-idea.875 & & \\
E-ISSN: & 2684-883X & & \\
Published by: & Ridwan Institute
\end{tabular}


Peningkatan aktivitas dapat terlihat dari nilai rata-rata siklus I sebesar 42,85\%, di siklus II sebesar 59,52\% dan siklus III sebesar 90,48 \% ; b. Perencanaan guru dalam menyiapkan pembelajaran siklus I skor 4,58, siklus II skor 4,68 dan siklus III skor 5,00 dan Proses pembelajaran pada siklus I skor 3,78, pada siklus II skor 4,35 dan siklus III skor 4,75; c. Hasil belajar siswa, sebelum perlakuan siswa yang tuntas ada $5(14,29 \%)$, siklus I ada $11(31,43 \%)$, siklus II ada $18(51,43 \%)$ dan siklus III ada $30(85,71 \%)$. Maka dapat disimpulkan bahwa penggunaan Model Learning tipe Group Investigation dapat meningkatkan aktifitas peserta didik yang pada gilirannya akan meningkatkan hasil belajarnya.

Kata Kunci: hasil belajar; model belajar kooperatif; tipe group investigation

\section{Pendahuluan}

Berdasarkan hasil observasi dan kajian awal sebagai guru mata pelajaran kimia diperoleh fakta bahwa aktifitas dan hasil belajar peserta didik kelas XII IPA masih rendah. Kelas XII IPA 1 yang berjumlah 35 siswa pada hasil ulangan harian materi sebelumnya yaitu sifat koligatif larutan sebagian sebagian besar memperoleh nilai dibawah KKM yang ditetapkan sekolah adalah 75. Dari 35 peserta didik kelas XII IPA 1 yang mendapat nilai di atas KKM hanya 2 siswa dan sisanya sebanyak 33 siswa mendapat nilai sama atau dibawah KKM. Persentase ketuntasan klasikal untuk siswa yang mencapai KKM sebesar $16 \%$ sedangkan presentase ketuntasan klasikal siswa yang belum mencapai KKM sebesar $84 \%$.

Tidak ada belajar kalau tidak ada aktivitas. Dalam kegiatan belajar, subyek didik atau siswa harus aktif berbuat. Dengan kata lain, bahwa dalam belajar sangat diperlukan adanya aktivitas (Yensy, 2012). Hasil belajar dapat disebut juga prestasi belajar menurut (Nurdyansyah \& Fitriyani, 2018). Prestasi adalah hasil yang telah dicapai seseorang dalam melakukan kegiatan (Hamdu \& Agustina, 2011). Prestasi Belajar dibedakan menjadi lima aspek, yaitu : kemampuan intelektual, strategi kognitif, informasi verbal, sikap dan keterampilan (Lomu \& Widodo, 2018). Hasil belajar dibedakan menjadi tiga aspek yaitu kognitif, afektif dan psikomotorik (Rahayu, Susanto, \& Yulianti, 2011).

Menurut (Suratman, Afyaman, \& Rakhmasari, 2019)"mendefinisikan hasil belajar sebagai tingkat penguasaan yang dicapai oleh pelajar dalam mengikuti proses belajar mengajar sesuai dengan tujuan pendidikan yang ditetapkan”.

Kondisi dari hasil survey guru, mungkin disebabkan kurang terlibatnya peserta didik dalam proses pembelajaran, sehingga menyebabkan hubungan siswa dengan pelajaran dan dengan gurunya semakin menjauh (Aisyah \& Koryati, 2017). Anggapan bahwa pelajaran kimia merupakan kumpulan konsep dan lambang-lambang yang sulit menjadi semakin melekat. Persepsi ini juga bukan hal baru. Bahkan di tahun 2005, BBC melaporkan temuan survei yang menemukan sekitar " $51 \%$ remaja menganggap pelajaran sains membosankan, membingungkan atau sulit. Jelas, menjadi problem bersama untuk dicarikan solusinya.

Berdasarkan latar belakang diatas, guru perlu mengambil langkah-langkah perbaikan untuk mendesain suatu model pembelajaran yang aktif, inovatif dan menyenangkan dengan menerapkan model pembelajaran kooperatif tipe Group 
Investigation. Menurut (Rudiansyah, Amirullah, \& Yunus, 2016) guru berperan sebagai fasilitas dalam membimbing siswa menyelesaikan materi atau tugas. Pembelajaran kooperatif merupakan sistem pengajaran yang memberi kesempatan kepada anak didik untuk bekerjasama dengan sesama siswa dalam tugas-tugas yang terstruktur, pembelajaran kooperatif juga disebut sebagai pembelajaran gotong royong (Esminarto, Sukowati, Suryowati, \& Anam, 2016). Diharapkan melalui model pembelajaran ini peserta didik akan menemukan sendiri obyek belajarnya secara benar dan optimal.

Dengan mendalami tujuan dan manfaatnya bagi perbaikan pembelajaran, peneliti merasa perlu untuk melakukan suatu penelitian tindakan kelas dengan judul "Penerapan model pembelajaran Kooperatif tipe Group Investigation untuk meningkatkan Hasil Belajar peserta didik".

\section{Metode Penelitian}

Metode Penelitian dilakukan dengan Tindakan (action research) atau siklus sebanyak tiga putaran. Setiap putaran terdiri dari empat tahap yaitu: Rancangan, (Planning), Pelaksanaan Kegiatan dan pengamatan (Acting), Observasi (Observing), dan Refleksi/Tindakan (reflecting) dan Teknik analisa data yang digunakan dengan melakukan prosentasi dari tabulasi data.

Tujuan PTK adalah memperbaiki dan meningkatkan kualitas pembelajaran serta membantu memberdayakan guru dalam memecahkan masalah pembelajaran di sekolah (Muslich, hal. 10). Menurut (Siregar, 2014): mengemukakan manfaat PTK bagi guru, yaitu: (1) Membantu guru memperbaiki mutu pembelajaran, (2) Meningkatkan profesionalitas guru, (3) Meningkatkan rasa percaya diri guru, (4) Memungkinkan guru secara aktif mengembangkan pengetahuan dan keterampilannya

Penelitian Tindakan ini dilaksanakan di SMA Negeri 2 Leuwidamar Kabupaten Lebak Provinsi Banten di kelas XII IPA1 pada Tahun pelajaran 2018/2019 semester ganjil dengan jumlah peserta didik 35 orang, terdiri dari 11 siswa perempuan dan 24 siswa laki-laki.

Subjek dalam penelitian ini adalah peserta didik kelas XII IPA-1 SMA Negeri 2 Leuwidamar Kabupaten Lebak dan Objek dalam penelitian ini adalah Model Pembelajaran Kooperatif tipe Group Investigation.

\section{Hasil dan Pembahasan}

\section{Hasil}

\section{A. Kondisi Awal}

Kelas XII IPA-1 sebelum dilakukan tindakan atau perlakuan dengan Group Investigation diberikan Pre-Tes dengan soal yang berhubungan dengan materi sebelum reaksi redoks, yaitu Sifat koligatif larutan yang diajarkan dengan pembelajaran konvensional, ternyata memberikan hasil yang kurang memuaskan, dimana jumlah siswa yang dapat menjawab soal dengan baik kurang dari $25 \%$. 
Hal ini, mungkin dapat dijelaskan sebagai berikut : Pada pembelajaran konvensional atau ceramah, gurulah yang menjadi pemeran utama atau satusatunya sumber informasi dalam proses pembelajaran dalam kelas, sedangkan siswa belajar hanya mendengarkan ceramah yang disampaikan oleh guru (Utami, 2017). Keadaan ini berakibat peserta didik menjadi apatis terhadap proses belajarnya, terutama bagi siswa yang kurang pandai. Mereka mengalami kesulitan dalam mengatasi masalah-masalah dalam membangun pemahaman dan penguasaan konsep. Siswa tertentu kadang-kadang menghindari bertanya kepada guru karena adanya ketakutan akan diberi pertanyaan balik yang tidak mampu dijawabnya.

\section{B. Pelaksanaan tindakan}

\section{Aktivitas Peserta didik}

Kegiatan pembelajaran dilakukan tiga siklus. Baik Siklus I, II dan III dilakukan selama dua kali pertemuan (empat jam pelajaran), dengan skenario pembelajaran yang telah dibuat, dimana pertemuan pertama dilakukan dengan mengamati aktivitas peserta didik dalam pembelajaran menggunakan model pembelajaran Group Investigation, sedangkan kegiatan tes hasil belajar dilakukan pada pertemuan kedua sekaligus melaksanakan pembahasan serta perencanaan kegiatan pada siklus berikutnya

Tabel 1

Rekapitulasi aktivitas peserta didik dalam pembelajaran pada siklus i, siklus ii dan siklus iii

\begin{tabular}{cccccccc}
\hline \multirow{2}{*}{ No } & \multirow{2}{*}{ Aktivitas } & \multicolumn{6}{c}{ Jumlah Siswa } \\
\cline { 3 - 8 } & & \multicolumn{2}{c}{ Sklus I } & \multicolumn{2}{c}{ Sklus Ii } & \multicolumn{2}{c}{ Siklus Iii } \\
\cline { 3 - 8 } & & Jml & \% & Jml & \% & Jml & \% \\
\hline 1 & Bekerja sama & 21 & 60 & 26 & 74,28 & 35 & 100 \\
\hline 2 & Fokus pada pembelajaran & 17 & 48,57 & 23 & 65,71 & 32 & 91,43 \\
\hline 3 & Mengajukan pertanyaan & 15 & 42,85 & 20 & 57,14 & 30 & 85,71 \\
\hline 4 & Menjawab pertanyaan & 15 & 42,85 & 20 & 57,14 & 30 & 85,71 \\
\hline 5 & Mengemukakan pendapat & 13 & 37,14 & 19 & 54,28 & 31 & 88,57 \\
\hline 6 & Mencatat/merangkum & 11 & 31,43 & 17 & 48,57 & 32 & 91,43 \\
\hline & Rata - Rata & 15.33 & 42.85 & 20.83 & 59.52 & 31.67 & 90.48 \\
\hline
\end{tabular}

Dari data pada tabel 2 yang diperoleh dari pelaksanaan observasi oleh pengamat terhadap aktivitas belajar siswa dengan mempergunakan model pembelajaran kooperatif tipe Group Investigation dapat diketahui apakah aktivitas siswa rendah, cukup, tinggi atau tinggi sehingga dapat diketahui peningkatan aktivitas yang diharapkan. Aktivitas siswa pada tabel dapat diketahui peningkatan aktivitas yang diharapkan. Aktivitas siswa pada tabel dapat diukur secara kualitatif dan kuantitatif (Istiana, Saputro, \& Sukardjo, 2015). Untuk menentukan kriteria tersebut dipakai kriteria yang dikemukakan oleh Suharsimi Arikunto dalam Teknik Evaluasi (1972, hal. 71), yaitu: 
a. $80-100$ : Aktivitas siswa sangat tinggi

b. $60-80$ : Aktivitas siswa tinggi

c. $40-60$ : Aktivitas siswa cukup

d. $20-40$ : Aktivitas siswa rendah

e. $0-20$ : Aktifitas siswa sangat rendah

Berdasarkan data pada tabel dapat ditarik suatu kesimpulan bahwa siswa telah menampakkan peningkatan aktivitas baik dari siklus I ke siklus II dan ke siklus III. Hal ini dapat terlihat dari persentase rata-rata siswa yang aktif dalam belajar makin meningkat.

Selain aktivitas secara individu. Dalam pelaksanaaan pembelajaran juga diamati aktivitas siswa secara kelompok, Adapun hasil pengamatan aktivitas siswa secara kelompok digambarkan seperti tabel berikut ini :

Tabel 2

Prosentase Kenaikan Kinerja Kelompok Model Pembelajaran Kooperatif tipe GI

\begin{tabular}{clccc}
\hline No & \multicolumn{1}{c}{ Nama Kelompok } & Siklus 1 & Siklus 2 & Siklus 3 \\
\hline 1 & Penyetaraan Reaksi Redoks (A) & 55.55 & 63.89 & 88.89 \\
\hline 2 & Sel Volta (B) & 33.33 & 52.78 & 86.11 \\
\hline 3 & Aplikasi Sel Volta (C) & 33.33 & 47.22 & 88.89 \\
\hline 4 & Korosi/Perkaratan (D) & 56.67 & 63.33 & 96.67 \\
\hline 5 & Hukum Faraday (E) & 41.67 & 61.11 & 88.89 \\
\hline 6 & Reaksi Elektrolisis (F) & 44.44 & 69.44 & 94.44 \\
\hline \multicolumn{2}{r}{ Rata - Rata } & $\mathbf{4 4 . 1 7}$ & $\mathbf{5 9 . 6 3}$ & $\mathbf{9 0 . 6 5}$ \\
\hline
\end{tabular}

\begin{tabular}{clc}
\hline Skore & \multicolumn{1}{c}{ Kriteria } & Nilai \\
\hline 5 & Sangat Baik & $>91$ \\
\hline 4 & Baik & $71-90$ \\
\hline 3 & Cukup baik & $51-70$ \\
\hline 2 & Kurang Baik & $31-50$ \\
\hline 1 & Tidak baik & $<30$ \\
\hline
\end{tabular}

Dari tabel 2 diatas diperoleh bahwa terdapat kenaikan aktivitas diskusi kelompok dalam hal intensitas keseriusan dalam penyelidikan suatu topik materi, interaksi antara anggota-guru-materi dan juga bimbingan dari guru akan sangat membantu dalam menyiapkan laporan, untuk selanjutnya dapat presentasikan.

\section{Hasil Belajar Peserta didik}

Kegiatan untuk memperoleh data tentang hasil belajar peserta didik dilakukan tes. Hasil belajar dilakukan pada pertemuan kedua sekaligus melaksanakan pembahasan serta perencanaan kegiatan pada siklus berikutnya 
(Amir \& Kurniawan, 2020). Hasil belajar dari tindakan pada siklus I, II dan III ditampilkan pada tabel sebagai berikut :

Tabel 3

Rekapitasi ketuntasan hasil belajar peserta didik dalam pembelajaran dengan model pembelajaran kooperatif tipe investigation siklus I, siklus II, dan siklus III

\begin{tabular}{cccccc}
\hline \multirow{2}{*}{ No } & \multirow{2}{*}{ Ulangan/Siklus } & \multicolumn{2}{c}{ Tuntas } & \multicolumn{2}{c}{ Tidak Tuntas } \\
\cline { 3 - 6 } & & Jml & $\%$ & Jml & $\%$ \\
\hline 1 & Pre Tes (Sebelum Perlakuan) & 5 & 14.29 & 30 & 85.71 \\
\hline 2 & Ulangan Harian Siklus 1 & 11 & 31.43 & 24 & 68.57 \\
\hline 3 & Ulangan Harian Siklus 2 & 18 & 51.43 & 17 & 48.57 \\
\hline 4 & Ulangan Harian Siklus 3 & 30 & 85.71 & 5 & 14.29 \\
\hline
\end{tabular}

Dari tabel 4 di atas terlihat adanya peningkatan hasil belajar kimia peserta didik. Sebelum perlakuan jumlah peserta didik yang tuntas hanya 5 orang. Pada siklus I jumlah peserta didik yang tuntas adalah 11 orang atau $14,29 \%$, batas nilai tuntas adalah 75 (sesuai dengan KKM). Sedangkan pada siklus II terdapat 18 orang atau 51,43\% yang tuntas belajar. Pada siklus III jumlah peserta didik yang tuntas naik mencapai 30 orang atau 85,71\%, sehingga telah melebihi $85 \%$ sebagai batas tuntas klasikal.

\section{Pembahasan}

\section{Aktivitas Peserta didik}

a. Dari tabel 1 diatas terlihat kenaikan aktivitas belajar individu peserta didik yang diamati. Aktifitas 1 yaitu jumlah peserta didik yang bekerja sama dalam diskusi kelompok, pada siklus I ada 21 orang (60\%), pada siklus II naik menjadi 26 orang (74,28\%), sedangkan pada siklus III naik lagi menjadi 35 orang (100\%). Artinya pada siklus III seluruh siswa berinteraksi dalam proses pembelajaran.

b. Tabel 1 terlihat peningkatan jumlah peserta didik yang fokus pada pembelajaran secara individu pada siklus I ada 17 orang (48,57\%), pada siklus II menjadi 23 orang $(65,71 \%)$ dan siklus III meningkat menjadi 32 orang $(91,43 \%)$

c. Dari table 1 terlihat peserta didik yang bertanya dan menjawab juga semakin meningkat, pada siklus I ada 15 (42,85\%), siklus II ada 20 orang (57,14\%), dan siklus III ada 30 orang $(88,57 \%)$

d. Sedangkan peserta didik yang berpendapat pada table 1 terlihat peningkatan, pada siklus I ada 13 orang (37,14\%), siklus II ada 19 orang $(54,28 \%)$ dan pada siklus III menjadi 31 orang $(88,57 \%)$.

e. Serta aktivitas peserta didik secara individu dalam mencatat dan membuat rangkuman juga semakin meningkat, pada siklus I ada 11 orang $(31,43 \%)$, 
siklus II ada 17 orang (48,57\%), dan pada siklus III menjadi 32 orang $(91,43 \%)$.

Dari keenam aktivitas peserta didik di atas dari siklus I, II dan III dapat dirangkum dalam tabel sebagai berikut :

\begin{tabular}{|l|r|r|r|}
\hline \multicolumn{1}{|c|}{ Aktifitas } & \multicolumn{1}{|c|}{ Siklus I } & \multicolumn{1}{c|}{ Siklus II } & Siklus III \\
\hline Bekerja sama & 21 & 26 & 35 \\
\hline Fokus belajar & 17 & 23 & 32 \\
\hline Bertanya & 15 & 20 & 30 \\
\hline Menjawab & 15 & 20 & 30 \\
\hline Berpendapat & 13 & 19 & 31 \\
\hline mencatat/merangkum & 11 & 17 & 32 \\
\hline
\end{tabular}

Dalam bentuk grafik sebagai berikut :

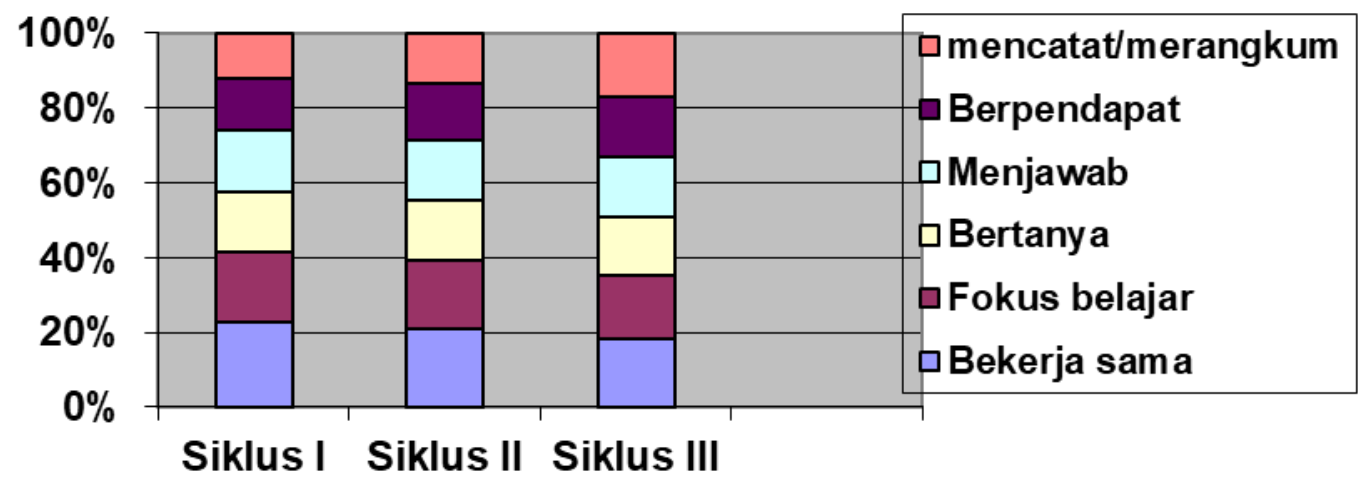

Grafik 1. Pembelajaran Kooperatif Investigasi konsep Reaksi Redoks

\section{Hasil Belajar Peserta didik}

Dari tabel diatas terlihat adanya peningkatan hasil belajar kimia peserta didik. Pada siklus I jumlah peserta didik yang tuntas adalah 11 orang, dan 24 orang lainnya dinyatakan belum tuntas karena belum mencapai nilai 75 (sesuai dengan KKM). Pada siklus II meningkat menjadi 18 orang yang tuntas belajar dan 17 peserta didik yang belum tuntas. Sedangkan pada siklus III jumlah peserta didik yang tuntas naik mencapai 30 orang dan masih ada 5 orang belum tuntas. Karena jumlah peserta didik yang tuntas pada siklus III telah melebihi $85 \%$, maka penelitian tindkaan kelas yang dilakukan guru sudah dinyatakan berhasil. Artinya penggunaan Group Investigation dalam melaksanakan pembelajarn pokok bahasan reaksi redoks dan Elektrokimia di SMA Negeri 2 Leuwidamar Kabupaten Lebak Tahun 2018 terbukti dapat meningkatkan hasil belajar peserta didik. Peningkatan peserta didik yang tuntas belajar digambarkan pada tabel sebagai berikut :

\begin{tabular}{|l|r|r|r|r|r|}
\hline & Pre tes & S I & S II & \multicolumn{1}{|c|}{ S III } \\
\hline Tuntas & $\mathbf{5}$ & $\mathbf{1 1}$ & $\mathbf{1 8}$ & $\mathbf{3 0}$ \\
\hline Tidak Tun & $\mathbf{3 0}$ & $\mathbf{2 4}$ & $\mathbf{1 7}$ & $\mathbf{5}$ \\
\hline
\end{tabular}

Dalam bentuk grafik sebagai berikut 


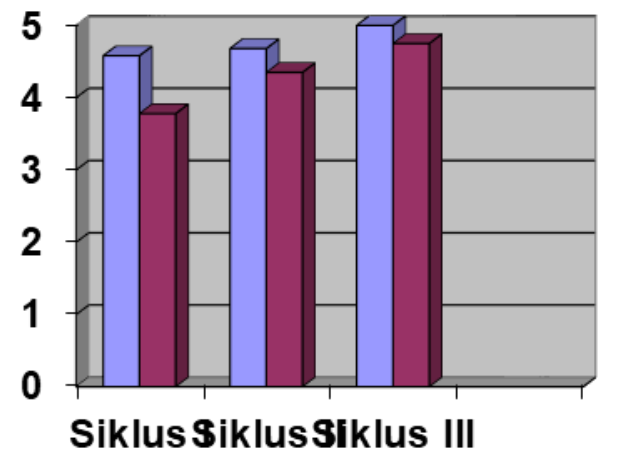

\section{Grafik 2 \\ Jumlah Peserta didik "Tuntas"}

Dari grafik diatas terlihat adanya peningkatan prosentase peserta didik yang tuntas belajar dan pada siklus III peserta didik yang tuntas sudah melebihi $85 \%$, yaitu sebesar $85,71 \%$ berarti tuntas secara klasikal, sehingga penelitian dapat dikatakan telah berhasil.

\section{Kesimpulan}

Berdasarkan hasil penelitian dan pembahasan, dapat disimpulkan bahwa : (1.) Aktifitas peserta didik baik individu maupun kelompok meningkat secara berturut-turut dalam proses pembelajaran mulai dari siklus I, II dan siklus III. (2.) Hasil belajar sebelum perlakukan hanya 14,29 \%, meningkat pada siklus I menjadi $31,43 \%$ dan siklus II meningkat menjadi 51,43\%. (3.) Pada siklus III ketuntasan klasikal sudah melebihi $85 \%$ 


\section{BIBLIOGRAFI}

Aisyah, Riswan Jaenudin, \& Koryati, Dewi. (2017). Analisis Faktor Penyebab Rendahnya Hasil Belajar Peserta Didik pada Mata Pelajran Ekonomi di SMA Negeri 15 Palembang. Jurnal Profit, 4(1), 1-11.Google Scholar

Amir, Mohammad Faizal, \& Kurniawan, Machful Indra. (2020). Penerapan pengajaran terbalik untuk meningkatkan hasil belajar mahasiswa PGSD UMSIDA pada materi pertidaksamaan linier. PEDAGOGIA: Jurnal Pendidikan, 5(1), 13-26. Google Scholar

Esminarto, Esminarto, Sukowati, Sukowati, Suryowati, Nur, \& Anam, Khoirul. (2016). Implementasi Model Stad dalam Meningkatkan Hasil Belajar Siwa. BRILIANT: Jurnal Riset Dan Konseptual, 1(1), 16-23. Google Scholar

Hamdu, Ghullam, \& Agustina, Lisa. (2011). Pengaruh motivasi belajar siswa terhadap prestasi belajar IPA di sekolah dasar. Jurnal Penelitian Pendidikan, 12(1), 90-96.

Istiana, Galuh Arika, Saputro, Agung Nugroho Catur, \& Sukardjo, dan J. S. (2015). Penerapan Model Pembelajaran Discovery Learning untuk Meningkatkan Aktivitas dan Prestasi belajar pokok bahasan larutan penyangga pada siswa kelas xi ipa Semester II sma negeri 1 ngemplak Tahun pelajaran 2013/2014. Jurnal Pendidikan Kimia, 4(2), 65-73. Google Scholar

Lomu, Lidia, \& Widodo, Sri A. (2018). Pengaruh motivasi belajar dan disiplin belajar terhadap prestasi belajar matematika siswa. Prosiding Seminar Nasional Pendidikan Matematika Etnomatnesia, 745-751. Google Scholar

Nurdyansyah, Nurdyansyah, \& Fitriyani, Toyiba. (2018). Pengaruh Strategi Pembelajaran Aktif Terhadap Hasil Belajar Pada Madrasah Ibtidaiyah. Universitas Muhammadiyah Sidoarjo. Google Scholar

Rahayu, Esty, Susanto, H., \& Yulianti, D. (2011). Pembelajaran sains dengan pendekatan keterampilan proses untuk meningkatkan hasil belajar dan kemampuan berpikir kreatif siswa. Jurnal Pendidikan Fisika Indonesia, 7(2). Google Scholar

Rudiansyah, Rudiansyah, Amirullah, Amirullah, \& Yunus, Muhammad. (2016). Upaya Guru dalam Mengatasi Kecemasan Siswa dalam Menghadapi Tes (Pencapaian Hasil Belajar) Siswa di SMP Negeri 3 Banda Aceh. Jurnal Ilmiah Mahasiswa Pendidikan Kewarganegaraan, 1(1). Google Scholar

Siregar, Ellys. (2014). Pengembangan profesionalisme guru melalui penelitian tindakan kelas. Jurnal Pengabdian Kepada Masyarakat, 20(77). Google Scholar

Suratman, Asep, Afyaman, Dadi, \& Rakhmasari, Rifa. (2019). Pembelajaran berbasis TIK terhadap hasil belajar matematika dan motivasi belajar matematika siswa. Jurnal Analisa, 5(1), 41-50. Google Scholar 
Rachmat Arif Ibrahim

Utami, Suerlin Diah. (2017). Perbedaan Penggunaan Model Pembelajaran Kooperatif Tipe Two Stay Two Stray (TSTS) dan konvensional terhadap hasil belajar siswa pada mata pelajaran IPS Kelas VIII SMPN 3 Kebumen. Universitas Negeri Semarang.Google Scholar

Yensy, Nurul Astuty. (2012). Penerapan model pembelajaran kooperatif tipe examples non examples dengan menggunakan alat peraga untuk meningkatkan hasil belajar siswa di kelas VIII SMP N 1 Argamakmur. Exacta, 10(1), 24-35. Google Scholar

\section{Copyright holder :}

Rachmat Arif Ibrahim (2021)

First publication right :

Journal Syntax Idea

This article is licensed under:

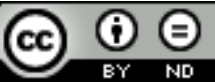

